\title{
EEN STUDIEREIS NAAR DE WEST
}

\author{
DOOR \\ MR. DR. L. N. DECKERS \\ V (Slot)
}

BRITSCH-GUYANA. SURINAME. FRANSCH-GUYANA.

De gelegenheid om met Britsch-Guyana kennis te maken mocht ik niet ongebruikt laten. Per K.N.S.M. ging ik van Willemstad naar Georgetown, de hoofdstad van het Engelsche gebied, dat zich uitstrekt van Venezuela tot de Corantijne. Het is $230.000 \mathrm{~km}^{2}$ groot en telt 320.000 inwoners, waaronder ongeveer 7.000 Indianen. Alleen de kuststreek is in cultuur, t.w. omstreeks 70.000 ha, waarvan het suikerareaal de helft in beslag neemt. Suiker en haar derivaten vormen dan ook de voornaamste uitvoerproducten. De imperiale economische politiek van het Britsche Rijk heeft de productie de laatste jaren eenigszins loonend doen blijven.

Verdere uitvoerproducten zijn vooral balata, hout en rijst. De geheele uitvoerwaarde beloopt ongeveer 2 millioen $€$ 's jaars.

De suikerplantages hebben niet zonder moeite de noodige arbeidskrachten kunnen verkrijgen. In het land zelf waren er niet genoeg beschikbaar. Vele vrij geworden Afrikaansche negers zijn ingevoerd omstreeks het midden van de vorige eeuw. Ook van China uit werd de immigratie bevorderd, maar er kwam reeds na enkele jaren een einde aan, daar men niet wenschte te voldoen aan de voorwaarde, dat de immigranten, na afloop van hun overeenkomst, voor rekening van de kolonie naar hun vaderland zouden kunnen terugkeeren.

Langs de kust worden bananien, ananas, sinaasappels en grapefruit geteeld. Verder verbouwt de bevolking maïs, cassave en zoete aardappelen.

In het binnenland vindt men uitgestrekte oerwouden met 
prachtige boomen, waarvan vele met orchideeën zijn bedekt.

De oevers der breede stroomen zijn met fraaie palmen bezet. De grootste der waterlelies, de victoria regia, is hier inheemsch.

In Britsch-Guyana leven de tapir, de poema en de jaguar, herten, apen en miereneters en verschillende soorten van slangen. Men vindt er allerlei vogels: duiven, eenden, snippen, kanaries en papegaaien.

Buiten de plantages wordt de landbouw op primitieve wijze beoefend. Slechts langzamerhand brengt de landbouwkundige dienst hierin verbetering.

Te Georgetown bevindt zich een mooie Botanische Tuin, waarin onder meer pracht-exemplaren van de victoria regia vallen te bewonderen. Ook bezit de hoofdstad een zeer goed natuur-historisch museum, waarin de geheele fauna van BritschGuyana is vertegenwoordigd.

De kolonie is niet ongezond. Zondert men de zeer warme maanden van windstilte, Augustus en September, uit, dan is de gemiddelde temperatuur $80^{\circ} \mathrm{F}$. Men onderscheidt twee natte en twee droge jaargetijden, die echter niet steeds even regelmatig zijn, zoodat een abnormaal langdurige droogte evenmin tot de uitzonderingen behoort als een ongewoon overvloedige regen.

De ziekte, welke de meeste slachtoffers maakt, is de tuberculose. Dit is vooral te wijten aan het gebrek aan hygiënisch inzicht bij de bevolking en ongetwijfeld niet minder aan de primitieve behuizing van zeer vele inheemschen. Sedert eenige jaren wordt op de volksscholen onderwijs gegeven in de gezondheidszorg.

Britsch-Guyana is de eenige Engelsche bezitting in ZuidAmerika. Ongeveer twee eeuwen lang woei er de Nederlandsche vlag en nog in menig opzicht leeft de herinnering aan het Nederlandsch bestuur er voort. Telkens weer ontmoet men Nederlandsche namen: Vreedenhoop, Uitvlugt, Beterverwagting, Fort Nassau, New-Amsterdam, Stabroek ${ }^{1}$ ).

Merkwaardig is, dat het Nederlandsche burgerlijk recht zich vrijwel wist te handhaven. Het strafrecht is Engelsch.

Britsch-Guyana wordt bestuurd door een Gouverneur, bijgestaan door een Wetgevenden Raad van 29 leden. 19 hunner worden gekozen door de bevolking, de overigen benoemd door den Gouverneur.

1) De naam van Georgetowns overdekte markt. 
Staatkundig is het gebied ingedeeld in drie „counties”: Berbice, Demerara en Essequibo.

Zee- en landmacht zijn in de kolonie niet vertegenwoordigd, maar het politiekorps is op militairen voet georganiseerd.

De Gouverneur van Britsch-Guyana, Sir Wilfred Jackson, heeft mij vergezeld op een bezoek aan het landbouwproefstation, de irrigatiewerken en de proefstallen. Hij geeft zich veel moeite om landbouw en veeteelt vooruit te brengen en nieuwe methodes ingang te doen vinden. Maar het was niet alleen daarover, dat wij spraken. Vier jaren te voren, in 1934, was Sir Jackson nog Gouverneur van Mauritius en nauwelijks had ik met Zijne Excellentie kennis gemaakt of hij sprak er zijn vreugde over uit den oud-minister te kunnen ontmoeten, onder wiens verantwoordelijkheid $\mathrm{Hr}$. Ms. Onderzeeboot K XVIII de 22.000 mijlen-lange reis van Nederland, over Dakar, Rio de Janeiro, Buenos Aires, Kaapstad en Fremantle, naar Soerabaia had gemaakt en bij die gelegenheid ook Mauritius had bezocht. De Gouverneur kende nog vele bijzonderheden van dezen merkwaardigen, door hem zoo zeer bewonderden tocht en toonde mij eenige, mij nog onbekende foto's, welke er betrekking op hebben. Het was een blijde verrassing en aan de Nederlandsche namen van Georgetown werden er tijdelijk eenige toegevoegd: Hetterschij, Vening Meinesz, Wijtema, Van der Linden, Leeuwenburg, Boskamp, Van der Linde....

Toen, na mijn vierdaagsch verblijf in Britsch-Guyana, Lady Jackson mij het voorrecht schonk van haar gezelschap in de motorsloep, die mij naar het vliegtuig van de P.A.A. moest brengen, waarmede ik naar Paramaribo zou gaan, sprak zij nog met geestdrift over die „famous sailors” van de K XVIII.

Het spreekt vanzelf, dat ik zeer heb verlangd naar de kennismaking met Suriname, Nederlands gebiedsdeel in Zuid-Amerika, waarover zoo veel is geschreven en gesproken, dat door eerbiedwaardige studiecommissies is bezocht en nadien veelzijdig in haar verslagen werd behandeld.

Suriname heeft zich niet, gelijk Curaçao, in industrieele richting ontwikkeld, doch is een landbouwland gebleven. Dit wil niet zeggen, dat het in cultuur is. Trouwens, hoe zouden 170.000 inwoners een land van $150.000 \mathrm{~km}^{2}$, dus ruim viermaal zoo groot als Nederland, in cultuur kunnen brengen? Alleen de alluviale kuststrook, $25 \mathrm{~km}$ breed in het oosten en westwaarts geleidelijk toenemend tot $100 \mathrm{~km}$, is in den loop der jaren nagenoeg geheel 
tot landbouwland gemaakt. Hierachter strekken de savannen haar schraal begroeide, dorre vlakten uit. Het overige deel van Suriname, $4 / 5$ van de totale oppervlakte, is goeddeels met bosch bedekt. Majestueuze oerwouden van reusachtige boomen in bonte verscheidenheid beslaan samen 16 millioen ha gronds. $\mathrm{Zij}$ vormen een dorado voor de Boschnegers, waarvan ons Guyana er ongeveer 17.000 herbergt en voor de Indianen, wier aantal op 3.500 wordt geschat. Een veelsoortige dierenwereld treft men in de bosschen aan: tapirs, leguanen, herten, brulapen en andere apen, wilde zwijnen, slangen, papegaaien, parkieten en colibri's.

De eerste vraag, die bij den bezoeker rijst - hoe dikwijls is zij reeds gesteld en min of meer beantwoord - is deze: hoe komt het, dat men in Suriname geen houtexploitatie vindt, zooals die b.v. op Java met zooveel succes wordt ondernomen? Aan de houtsoort ligt het niet. De schoonste van alle boomen, die fier zijn prachtige kruin boven alle andere uitsteekt, de kankantrie (cotton-tree), levert wel is waar geen bruikbaar hout op, maar het in Europa welbekende letterhout, het voor parketten toegepaste purperhart, het bruinhart, het ijzerhart, het tegen paalworm bestand zijnde geelhart en het mahoniehout bezitten ongetwijfeld handelswaarde. En toch hebben noch de boschexploitatie noch de houthandel een omvang van beteekenis aangenomen.

Een voorname oorzaak van dit uit economisch oogpunt betreurenswaardig verschijnsel is gelegen in het feit, dat Suriname bijna geen bosschen heeft van uitsluitend of nagenoeg uitsluitend een en dezelfde houtsoort. Allerlei soorten van boomen staan door elkaar. Een regelmatige exploitatie wordt hierdoor zeker niet bevorderd. Alleen den moraboom en de possontrie (poisontree) treft men in aaneengesloten hoeveelheden aan en ook hun hout leent zich tot bewerking.

Als tweede oorzaak van de geringe beteekenis van den houthandel wordt genoemd de onmogelijkheid om van de Boschnegers, de Surinaamsche houtkappers bij uitnemendheid, een geregelde levering te krijgen. En deze is noodig, wil men voortdurend kunnen exporteeren ten einde op tijd aan de vraag uit Europa te voldoen. Met zulke overwegingen van economische orde vermoeit de Boschneger zich echter niet. In zijn overdreven vrijheidsliefde wenscht hij zelf te bepalen wanneer hij zal hakken en wanneer hij zijn vlot in elkaar zal zetten om het gevelde hout langs de rivieren naar Paramaribo te voeren. Een order neemt hij aan, maar zelfs een order tot levering op termijn belet 
hem niet om zelf uit te maken wanneer de bestelling zal worden uitgevoerd. Die eigendunkelijkheid is een lastige eigenschap en zij zal nog heel wat getemperd moeten worden voordat de Boschneger een bruikbare schakel is geworden in den internationalen houthandel. In afwachting daarvan durf ik echter clementie te pleiten voor den houtkapper der Surinaamsche binnenlanden. $\mathrm{Hij}$ is een nazaat van de zedelijk en lichamelijk mishandelde slaven. Misschien slaagden zijn voorouders erin de hel te ontvluchten, waarin zij moesten leven en arbeiden en wisten zij, door zich schuil te houden in de diepten der wouden, aan de vervolgingen te ontkomen. Wellicht hebben zijn vaderen hun ellendig bestaan voortgesleept tot eindelijk, in 1863, door de afschaffing der slavernij, de ketenen werden verbroken. Eenmaal vrij, hebben die vaders en moeders van drie kwart eeuw geleden het is nergens geboekstaafd, maar het kan niet anders zijn zich zelf en hunnen kinderen bij al wat hun heilig was beloofd die vrijheid te bewaren en als hun eenigen schat tegen elke aanranding te beschermen. Deze vrijheidsliefde, levendig gehouden door de afschrikwekkende herinneringen uit den onvrijen tijd, werd overgedragen van vader op zoon. Het is niet hun schuld, dat de moderne beschaving haar nog niet heeft gebreideld.

Naarmate door godsdienst en cultuur - Missie en Zending doen hier reeds prijzenswaardig werk - de Boschnegers meer uit hun geestelijk isolement zullen worden verlost, zullen zij beter toegankelijk worden voor onze begrippen omtrent ,maatschappelijk verkeer" en geleidelijk een taak gaan vervullen in het internationaal productieproces.

Intusschen is de onbeteugelde vrijheidsliefde der Boschnegers naar mijn meening geen afdoende verklaring van het uitblijven der ontwikkeling van een Surinaamsche boschexploitatie. Nederlandsche ondernemingszin en ondernemingsdurf moeten toch kunnen leiden tot den aanleg van bosschen van bepaalde, goed bruikbare en zeer gewilde houtsoorten. Zijn deze er eenmaal, dan zal men komen tot betere cijfers voor den houtuitvoer dan die, welke wij in het Surinaamsch Verslag 1918 1) vermeld vinden, te weten:

$$
\begin{gathered}
\text { in } 1933 \text { voor } f \text { 72.181.- } \\
, 1934, \quad-84.495 .-
\end{gathered}
$$

1) Deel I, blz. 27. 


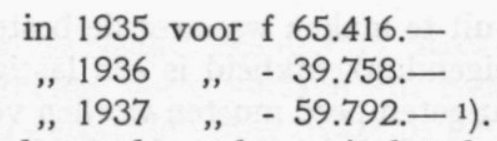

Ook thans reeds zouden echter uit het kostbare houtbezit meer baten zijn te trekken. Toen Suriname nog zijn Boschdienst had met de daaraan verbonden houtvesters is goed voorbereidend werk verricht o.a. op het gebied van onderzoek van de houtsoorten en nieuwe aanplantingen. Maar zooals het meer gebeurde, het ,,beid uw tijd” heeft men niet in acht genomen en voordat de dienst tastbare resultaten kon opleveren, werd hij om bezuinigingsredenen opgeheven. ${ }^{2}$ )

Is het met de cultures ook niet zoo gegaan? Aan proefnemingen heeft het niet ontbroken. Ik kan mij echter niet onttrekken aan den indruk, dat men, door welke oorzaken dan ook, zich meermalen te spoedig overwonnen heeft gegeven bij tegenslag.

Een halve eeuw geleden was de cacaocultuur in Suriname van groote beteekenis, niet alleen voor den groot-landbouw, de plantages, maar ook voor het klein-bedrijf. Op het einde der vorige eeuw bedroeg haar opbrengst meer dan 4.000 ton per jaar. De krullotenziekte heeft echter in enkele jaren tijds de meeste boomen vernietigd en nooit is de cultuur dezen slag te boven gekomen. Met de rubbercultuur ging het al even onvoorspoedig. Ook hier verijdelde een ziekte de schoone verwachtingen, welke men na een veelbelovend begin mocht koesteren. Het lot van de bacovencultuur was weinig beter. Reeds na den eersten uitvoer, mogelijk gemaakt door een overeenkomst met de machtige United Company, brak de Panamaziekte uit onder de aanplantingen der Gros Michel-bacoven en zij zou ongetwijfeld een einde hebben gemaakt aan de jonge cultuur, als de Surinaamsche Bananen Maatschappij, onder de energieke leiding van den onvermoeibaren heer Kasteleyn, niet met alle kracht de proefnemingen had voortgezet en de ziektebestrijding ter hand genomen. Vergezeld van den heer Ir. de Kraker, die de maatschappij in Suriname vertegenwoordigt, bezocht de heer Kasteleyn persoonlijk de voornaamste der Gros Michel produceerende landen om ter plaatse te onderzoeken wat men er

1) Hieronder voor $f$ 27.928. - naar Nederland.

2) Zie het Bijvoegsel tot de Nederlandsche Staatscourant van 28 September 1917, No. 227, houdende het rapport van Dr. A. H. Berkhout over het Surinaamsche Boschwezen. De rapporteur gewaagt met veel lof van den Dienst en van den arbeid van den houtvester, den heer Gonggrijp. 
deed om de Panamaziekte te bestrijden. In samenwerking met Prof. Dr. Stahel, directeur van het Landbouwproefstation, Dr. Fernandes, Directeur van het Departement van LandbouwEconomische Zaken en Dr. Müller, landbouwscheikundige bij het Proefstation, worden op het Surinaamsche bedrijf voortdurend wetenschappelijke proeven genomen en vergelijkingen getroffen tusschen verschillende soorten bananen, aangeplant onder uiteenloopende omstandigheden. Gros Michel, Congo en Laca$\tan$ zijn op uitgebreide schaal vertegenwoordigd en in den variëteitentuin neemt men proeven met een twintigtal verschillende soorten. We kunnen wel zeggen, dat op „Rust en Werk”, de plantage van de Surinaamsche Bananen Maatschappij, schier alles wordt toegepast wat noodig is om een afdoend antwoord te vinden op de vraag of de bananencultuur voor Suriname al dan niet aanbeveling verdient. In het omvangrijke en belangwekkende jaarverslag der maatschappij over 1938 vindt men de proefnemingen beschreven en de resultaten vermeld en duidelijk blijkt eruit hoe veel reeds werd geleerd en nog te leeren overblijft. De proefnemingen en onderzoekingen hebben betrekking op de soorten, den bodem, de grondbewerking, de wijze van beplanting, de bemesting, de bestrijding der plantenziekten o.m.door bespuitingen 1), de stamselectie, den invloed van dauw, regen en wind, het snoeien, de irrigatie en de samenstelling van het water. Deze opsomming maakt niet eens aanspraak op volledigheid. Vast is nu wel reeds komen te staan, dat de bananencultuur, gericht op den wereldhandel, beantwoorden moet aan vele eischen van kennis en zorg. Merkwaardig is de proef, welke werd genomen met het verbouwen van bananen door kleinboeren op de nederzetting Creola. Het verdient groote waardeering, dat de Surinaamsche Bananen Maatschappij hiertoe aan Dr. Fernandes de noodige medewerking verleende. Kosteloos stelde zij voor de settlers van Creola 20.000 knollen beschikbaar en zij verplichtte zich tegen te voren vastgestelde behoorlijke prijzen den eersten oogst af te nemen. Iedere settler kon 300 knollen ontvangen als hij de plantgaten daarvoor in orde maakte. Aan deze voorwaarde werd door 54 settlers voldaan. Het resultaat was echter nog niet mooi. Op een enkele goede

1) Reeds zes jaren lang heeft de bananencultuur in Zuid-Amerika, West-Indië en Centraal Amerika veel te lijden van de uit Australië afkomstige Cercospora-bladziekte. De groote fruitmaatschappijen bestrijden haar krachtdadig, maar onder de smallholders is dit uitzondering. 
uitzondering na, zegt het verslag, werd aan grondbewerking niets gedaan. Het onderhoud was zeer onvoldoende. Schade werd ondervonden door vreterij van kippen, van te hoog onkruid en bijcultures, als maïs en oker. Mede tengevolge van het laatste trad de bladziekte spoedig in ernstige mate op. Aan snoei en het stutten van de bosschen werd weinig of niets gedaan. Het oogsten gebeurde zeer slordig. Uit de gegevens is komen vast te staan, dat de grond van dien aard is, dat een goede eerste oogst verkregen kan worden. Ir. de Kraker wijt de slechte totaal-productie dan ook aan de te geringe zorg, door de settlers aan het gewas besteed.

De proef zou wellicht een beteren uitslag hebben opgeleverd als zij was genomen met Javanen of Britsch-Indiërs, die met meer toewijding in den landbouw werkzaam zijn dan de Creolen. Bewaren dezen nog niet altijd, bewust of onbewust, in het diepst van hun hart een zekere minachting voor den landarbeid, het „slavenwerk" van weleer? Toch moet men aan den klein-landbouw voor Surinames toekomst groote waarde toekennen en het stemt tot vreugde, dat deze cultuurvorm zich zoowel bij de Overheid als bij het particulier initiatief meer en meer in belangstelling gaat verheugen.

Het Departement van Landbouw-Economische Zaken en het Landbouwproefstation laten niet na door het geven van voorlichting en het bieden van steun den klein-landbouw te bevorderen. Over de bereikte resultaten, ook met de Creolen-vestigingen Creola, in het district Saramacca, Herminadorp aan de Marowijne en aan den Rijsdijkweg (werkloozen) is men tevreden. Samen tellen zij ongeveer 175 gezinnen.

De Missie heeft een nederzetting van Britsch-Indiërs te Gyrjapur en een van Javanen bij den Copieweg. Van beide krijgt de bezoeker een goeden indruk, ook voor wat de woningen betreft.

Met de vestiging van de Evangelische Broeder Gemeente in den Saramaccapolder is het niet voorspoedig gegaan. „Op deze vestiging", aldus lezen wij in het Surinaamsch Verslag 1938 1), „,bleef, niettegenstaande veel teleurstelling werd ondervonden van settlers, die in den aanvang goed begonnen, doch zich later terugtrokken, toch nog een kern van goede werkers over, die alles deden om in hun levensonderhoud te kunnen voorzien. Het kan echter niet worden ontkend, dat de toestand zich, wat deze vestiging betreft, niet hoopvol liet aanzien." In dit geval heeft

2) Deel I. Blz. 12 . 
men dus met tegenspoed te kampen. Het is niet de eerste, dien de Broedergemeente bij haar arbeid ontmoette. Zij laat zich hierdoor den moed niet ontnemen.

Moet de agrarische ontwikkeling van Suriname alleen in den klein-landbouw worden gezocht? Deze vraag zou ik niet bevestigend wenschen te beantwoorden. $\mathrm{Er}$ is een tijd geweest, dat in Suriname nauwelijks eenige andere landbouw werd gekend dan die van de plantages. Men telde ze bij honderdtallen, er werkten vele duizenden slaven en ze leverden aanzienlijke winsten op. Men heeft jaren gekend, waarin Suriname voor het Moederland meer baten afwierp dan Oost-Indië! Dat was de gouden tijd voor Suriname, hoort men meermalen zeggen. Geheel ten onrechte. Het was de gouden tijd voor de eigenaars van de plantages. Doch voor de menschen, die, slecht gevoed, meestal slecht en dikwijls schandelijk behandeld, op de plantages werkzaam waren? Voor hen was het een ellendige tijd. En voor Suriname zelf? Waar zijn de kunstwegen, welke men in dien tijd heeft aangelegd? Waar de scholen, de ziekenhuizen, de kerken, welke men in die dagen van weelde heeft gebouwd? Waar de Overheidsdiensten, welke men toen in het belang van de bevolking heeft gesticht? Ze zijn spoedig opgesomd. Bijna alles wat op dit gebied van Overheidswege of met Overheidshulp tot stand kwam dateert van lateren tijd. De plantages hadden haar beste jaren al lang achter den rug, doch langzamerhand had de overtuiging veld gewonnen, dat een kolonie meer is en beter dan een wingewest, welks bodem en bewoners er alleen zijn ten bate van het Moederland. Thans erkent een ieder en wil menigeen er naar handelen, dat wij het recht op het bewind over gebiedsdeelen elders zouden moeten prijsgeven indien wij niet den plicht aanvaardden om aan dat grondgebied en zijn bevolking te brengen de vruchten van godsdienst, cultuur en beschaving. Met deze opvatting is het stelsel der oude plantages niet vereenigbaar. Geenszins wil dit echter zeggen, dat de groot-landbouw voor Suriname uit den booze zou zijn. Goed geleide plantages, die onder redelijke arbeidsvoorwaarden werk bieden aan vele honderden handen, zijn zoowel in sociaal als in economisch opzicht van groote waarde. Zij staan den klein-landbouw niet in den weg, doch kunnen daarentegen, bij harmonische samenwerking, zijn ontwikkeling helpen bevorderen. Door het voorbeeld en door de daad. De bewerking van den bodem, de behandeling van het gewas, de bestrijding van de plantenziekten, dat 
alles kan de klein-landbouwer leeren door zijn voordeel te doen met de lessen der plantages. Bovendien kunnen deze, naar het voorbeeld van de Surinaamsche Bananen Maatschappij, den klein-landbouwers deugdelijk pootgoed leveren en den oogșt van hen afnemen. Van niet minder belang is, dat de handelsrelaties met het buitenland gemakkelijker door de groote ondernemingen worden aangeknoopt en onderhouden dan door de klein-landbouwers, onder wie coöperatie en vereenigingsleven naar Europeesch begrip nog weinig ingang hebben gevonden.

Gelijk bekend is werd door Gouverneur Kielstra, daarin overtuigingsvol gesteund door den Directeur van Landbouw-Economische Zaken, Dr. Fernandes, de bevordering van de citruscultuur met kracht aangepakt. Dr. Fernandes heeft in 1937 een studiereis gemaakt naar Florida, het meest op den voorgrond tredende citrusgebied. De resultaten van deze reis zijn neergelegd in een gedocumenteerd rapport, waarin er op wordt gewezen, dat de mogelijkheden voor de citruscultuur in Suriname, zoowel landbouwtechnisch als economisch, beter zijn dan in Florida, Louisiana en Mississippi. De ondervinding heeft geleerd, dat de door saprijkheid uitmuntende Surinaamsche sinaasappel in Europa afzet kan vinden. Gebleken is reeds, zei Dr. Fernandes in een rede, naar aanleiding van zijn studiereis gehouden, dat ook bij aanvoer van Braziliaansche en Spaansche sinaasappels in Nederland, de vraag naar het Surinaamsch product onverminderd bleef. 1) Volgens dezen deskundige kan een citrustuin van 16 ha na 12 tot 13 jaren het geheele kapitaal benevens de rente hebben opgebracht en vervolgens een jaarlijksche zuivere opbrengst van ten minste 6.000. Gld. verzekeren.

Naar het zich laat aanzien leent de citruscultuur zich bijzonder tot samenwerking tusschen den groot- en den klein-landbouw. $\mathrm{Zij}$ bevindt zich thans nog in het stadium van proefneming, of, wil men het eenigszins optimistischer zien, van voorbereiding. Een voorbereiding óók van den geregelden uitvoer en deugdelijke verscheping van het product naar Europa, met name naar Nederland en van de stichting van de noodige installaties voor de bereiding van derivaten. Daarbij zal echter rekening moeten worden gehouden met de beschikbare arbeids-

1) Citruscultuur in Suriname. Departement van Landbouw-Economische Zaken. Mededeeling No. 1. December 1937. Blz. 39. 
krachten. Ook Dr. Fernandes wees hierop in zijn evenbedoelde rede.

„De uitbreiding, welke men in Suriname onder de tegenwoordige omstandigheden zal mogen geven, is natuurlijk geen onbegrensde. Het zal niet raadzaam zijn meer sinaasappelboomen te planten dan men handen heeft om de vruchten te plukken.

„Bij de tegenwoordige arbeiderssterkte zou Suriname met een volproduceerend citrusareaal van 1000 ha reeds naar een maximum loopen. Dit zou een productie beteekenen van \pm 300.000 kratten per jaar of slechts $25 \%$ van de Nederlandsche consumptie van 1936." 1)

Sinds Dr. Fernandes zijn studiereis ondernam is de bevordering van de citruscultuur in Suriname krachtdadig voortgezet.

Door een maatregel van den Gouverneur werd aan de koffieplantages een ruimere steun verleend, indien zij de citrus als nevenproduct wenschten te aanvaarden en vele hebben zich hiertoe verbonden.

Van Gouvernementswege werd in het district Saramacca de citruskweekerij te Dirkshoop aangelegd. $\mathrm{Zij}$ is 5 ha groot en er werden 165.000 zuuroranje-onderstammen geplaatst. De sinaasappelplantjes zijn van geselecteerd materiaal, de Kwatta 202, die, na onderzoek door het Koloniaal Instituut te Amsterdam, de voor consumptie in Europa meest geschikte Surinaamsche sinaasappel werd bevonden. Het was mij een vreugde in deze mooi aangelegde en zorgvuldig onderhouden kweekerij rond te wandelen en de welig wassende sinaasappelplanten in oogenschouw te nemen. Een stuk economisch leven, rijk aan beloften. Er wordt werkelijk niet stil gezeten en klaarblijkelijk ontbreekt het bij de plantages en de settlers niet aan medewerking om de Surinaamsche citrus een goede kans te geven. In het Surinaamsch Verslag $1938^{2}$ ) lezen wij, dat de uitbreiding van de cultuur van sinaasappelen en andere citrussoorten in 1937 grooter was dan in alle voorgaande jaren en dat zij plaats vond zoowel bij den grooten als bij den kleinen landbouw. Op Dirkshoop werden 40.000 zuuroranje-onderstammen bijgeplant. De kweekerij leverde in 1937 bijna 39.000 geoculeerde citrusplantjes af. $70 \%$ ging naar de plantages, $30 \%$ naar den kleinlandbouw. Nabij de kweekerij is een variëteitentuin aangelegd, waarin de eigenschappen van een dertigtal citrussoorten worden onderzocht. Naast dezen tuin is een 60 ha groote sinaas-

1) Citruscultuur in Suriname. Blz. 37.

2) Deel I. Blz. 17 e.v. 
appelen-aanplant gemaakt, welke dient „om de zoo noodige gegevens te verzamelen betreffende de intensiviteit van de schaduw, de meest doelmatige bemesting, de gemiddelde productie per boom, de bestrijding van eventueele ziekten en plagen, enz. Deze aanplant is in feite een proefveld, maar van zoodanigen omvang, dat de verkregen gegevens meer in overeenstemming kunnen zijn met de ervaringen in de practijk, hetgeen niet steeds van kleine proefvelden kan worden gezegd."

Het is voldoende bekend, dat niet allen van de citruscultuur dezelfde goede verwachtingen koesteren als die, welke de autoriteiten bezielen, welke voor de in de laatste jaren in Suriname genomen maatregelen tot haar bevordering, het eerst verantwoordelijk zijn. Maar ik kan mij niet voorstellen, dat ook de minder optimistisch gestemde geen voorstander zou zijn van voortzetting der met zooveel ernst aangevangen proefnemingen. Voortzetten en niet versagen. Niet met koppigheid, die blind maakt voor de lessen van eventueel teleurstellende ervaringen, maar wel met taaie vasthoudendheid, die kracht schenkt tot de overwinning van moeilijkheden, welke er reeds zijn en ongetwijfeld nog zullen komen. Natuurlijk dient niet op één enkel paard gewed. De citrusteelt is een veeljarige cultuur. De opbrengsten beginnen, volgens de berekening van Dr. Fernandes, eerst na 12 tot 13 jaren te vloeien. Men deed ongetwijfeld met deze cultuur in Suriname reeds heel wat ondervinding op en vulde deze aan met de lessen der ervaring van elders. Maar veel blijft nog te ondervinden over. Men staat nog slechts aan het begin, een hoopgevend begin wel is waar, doch, dat niettemin de inleiding is tot een onbekende toekomst. Van zeer deskundige zijde werd hierop niet lang geleden gewezen. De heer J. D. Oppenheim, Tuinbouwconsulent bij het Departement van LandbouwEconomische Zaken in Suriname, zeide in een rede, welke hij in Februari van dit jaar te Paramaribo hield voor de Surinaamsche Landbouwvereeniging:

„De citruscultuur als zoodanig is hier nog zeer jong. Wij staan nog voor vele problemen. Problemen, zoowel van cultuurtechnischen, als van organisatorischen en industriëelen aard. Op ieder dezer gebieden zullen we door vallen en opstaan wijzer moeten worden. Ziekten en plagen zullen in de cultuur zeker niet uitblijven, vrijwel nergens was dit een reden, om een cultuur te verlaten" 1 ).

1) Departement van Landbouw-Economische Zaken. Mededeeling No. 2, Maart 1939. Blz. 37. 
Ook bij gegrond vertrouwen maant dit alles tot voorzichtigheid. Het lijkt mij dan ook noodig, dat de oude cultures niet worden verwaarloosd en dat haar, binnen redelijke grenzen, kans wordt geboden op verzekering van haar voortbestaan. Het moeilijkst staat er wel de koffiecultuur voor, eenmaal een bron van goede inkomsten, thans noodlijdend in den vollen zin van het woord. Bij al haar tegenspoeden kreeg zij in November 1937 nog den zwaren slag, dat de Braziliaansche Regeering haar stelsel van het hooghouden der koffieprijzen opgaf en door een verlaging van de uitvoerbelasting met $75 \%$ haar koffie de gelegenheid bood verloren markten te herwinnen en nieuw afzetgebied te veroveren. De koffieprijs daalde toen zoo belangrijk, dat de Surinaamsche plantages haar product beneden den kostprijs moesten verkoopen en al weer enkele den strijd moesten opgeven en tot stopzetting overgaan. Bij dezen stand van zaken is het lang niet zeker, dat de maatregelen, door de van Gouvernementswege gestichte Surinaamsche Koffiecentrale genomen en nog te nemen, in staat zullen zijn de koffiecultuur te redden. Volgens sommigen wordt de geldelijke hulp aan de plantages geboden onder te bezwarende voorwaarden. In het Surinaamsch Verslag 1938 1) wordt medegedeeld, dat de Centrale aan de ondernemingen in het algemeen voorschotten geeft ter goedmaking van de helft der in eenig jaar geleden substantiëele exploitatie-verliezen. Bovendien verstrekt zij de bedragen voor den aanleg van een bijcultuur van citrus naast de koffie. Deze steun wordt verleend tot een bedrag van $f$ 120.- per ha als subsidie en van $f$ 70.- per ha als leening. Dit laatste naar gelang van de behoeften en eerst nadat de ondernemer uit eigen middelen $f$ 60.- per ha voor de nieuwe cultuur heeft uitgegeven. Zal op deze wijze bereikt worden het eerste doel van de Koffiecentrale, ,het bevorderen eener goede verhouding en onderlinge samenwerking tusschen alle belanghebbenden in de koffie-cultuur en de behartiging hunner bedrijfsbelangen in technischen, commerciëelen en algemeen economischen zin"? Ik matig mij in dezen geen oordeel aan. Om hier tot oordeelen in staat te zijn moet men de geheele financieele en economische positie van de plantages kennen. Wel worden ontkennende beantwoordingen van de zooeven gestelde vraag vernomen. Zoo troffen mij de beschouwingen, welke de hoofddirecteur van de Surinaamsche Bank, Mr. van Traa, in het Verslag van 1937 aan de kwestie wijdt. „De ondernemingen, die toch al zwaar belast zijn

1) Deel I. Blz. 32. 
met de steunvoorschotten 1931 en 1933, die het Gouvernement, ondanks alle vertoogen van de zijde van belanghebbenden ten volle als vordering blijft handhaven, worden dus steeds verder met schuld aan de Overheid belast ${ }^{1}$ ).

Ook de volgende woorden verdienen alle aandacht:

„Indien men in het oog houdt dat de schulden aan het Gouvernement gedekt zijn door oogstverband, een verband waarvan de ondernemingen zelfs niet door executie kunnen worden gezuiverd, dan is het duidelijk dat deze wijze van steunverleening den eigenaren weinig baat zal kunnen brengen. Want, waar het ondenkbaar is dat vreemd kapitaal zich ooit zal interesseeren voor ondernemingen, wier toekomst belast is met verplichtingen van den aard zooals in Suriname daarop drukken, zal den eigenaren, wanneer hun eigen middelen zullen zijn uitgeput, niets anders overblijven dan hun bezit aan de Overheid over te laten.

„Het praktisch resultaat, waartoe de wijze, waarop in Suriname de koffiecultuur gesteund wordt, moet leiden zal n.m.m. geen ander kunnen zijn dan dat het particulier belang hoe langer hoe meer daaruit zal verdwijnen en het Gouvernement voor de keuze zal komen te staan, de cultuur als Gouvernementscultuur door te zetten of haar te niet te laten gaan." 2 )

In zijn verslag over 1938 uit Mr. van Traa zijn bezorgdheid over het vraagstuk der arbeidskrachten.

„Of het beter resultaat dat de koffiecultuur voor 1939 belooft tenvolle verwezenlijkt zal worden, zal echter in de eerste plaats afhankelijk zijn van de mogelijkheid tot voorziening in voldoende arbeidskrachten.

„Het arbeidersvraagstuk, waarop in deze verslagen reeds herhaalde malen gewezen is, vraagt hoe langer hoe dringender om een spoedige oplossing.

„Op vele plantages heerscht een groot tekort aan arbeiders, wat zich vooral doet gevoelen in den pluktijd. Honderden balen koffie gaan thans verloren omdat voldoende arbeidskracht ontbreekt om deze tijdig te kunnen plukken en het behoeft geen betoog dat daardoor de productiekosten zeer ongunstig beïnvloed worden. Zoowel de koffie- als de suikercultuur lijden onder deze moeilijkheid om voldoende arbeiders te kunnen verkrijgen, een moeilijkheid die nog zal toenemen wanneer de crisiscultuur straks ook weer vele handen zal vragen en die het eventueel

1) De Surinaamsche Bank N.V., Amsterdam. Verslag 1937. Blz. 4.

2) Ibid. Blz. 4 en 5 . 
tot stand komen van een bacovencultuur op groote schaal zal kunnen verhinderen.

„Naast het mobiel maken van de reeds in Suriname aanwezige werkkrachten zal daartoe noodig zijn de aanvoer van nieuwe arbeiders, doch deze aanvoer zal slechts resultaat kunnen opleveren, indien aan de plantages de beschikking over hun arbeidskracht wordt gegeven op niet al te bezwarende voorwaarden. Het schijnt echter dat de voornemens die het Gouvernement te dien aanzien koestert niet kunnen worden geacht aan dien eisch te voldoen ${ }^{1}$ ).

Men mag vertrouwen, dat deze van ernstige bezorgdheid getuigende klanken, die natuurlijk ook in Suriname werden vernomen, daar de overweging vinden, welke zij verdienen en zoo noodig leiden tot nieuw onderzoek en nader overleg.

Mijn indruk is, dat de andere cultures - suiker, rijst, maïs, tabak, cocosnoten - voldoende belangstelling ontvangen. Vooral van den rijstbouw, in Nickerie door de Javaansche klein-landbouwers beoefend, mag men goede verwachtingen hebben. Aan het vraagstuk van de veredeling van het product wordt alle aandacht besteed. Ook de cacaocultuur mag nog niet worden vergeten. Gaarne onderschrijf ik wat dienaangaande voorkomt in het Surinaamsch Verslag $1938^{2}$ ): „De cacaocultuur is weliswaar thans van weinig belang meer, doch niet geheel zonder beteekenis, als men in aanmerking neemt, dat de locale consumptie bijna geheel wordt gedekt door de binnenlandsche productie terwijl nog steeds een kleine hoeveelheid wordt uitgevoerd ${ }^{3}$ ). Een vergelijking van de gemiddelde productie per boom van de verwaarloosde aanplantingen in Suriname met die van andere cacao-produceerende landen, geeft wel aanleiding den wederopbouw van deze cultuur in Suriname in ieder geval niet voor goed te verwerpen."

Van belang zou het naar mijn meening zijn, dat voor Suriname een economisch ontwikkelingsplan werd vastgesteld. Dit zou kunnen geschieden door het Opperbestuur, in overleg met het Surinaamsche Gouvernement, voorgelicht door deskundigen in Nederland en Suriname. Zulk een plan moet niet tot in bijzonderheden afdalen, doch dient de groote lijnen aan te geven,

1) Blz. 5 en 6 .

2) Deel I. Blz. 21.

3) Productie 1937: $104.966 \mathrm{~kg}$. Uitvoer 1937: $5.264 \mathrm{~kg}$, ter waarde van $f$ 1.770.- 
waarlangs de ontwikkeling van het gebiedsdeel behoort te worden bevorderd.

Suriname zal weldra weer een nieuwen Gouverneur krijgen. In het beleid van den aftredenden Landvoogd zat ongetwijfeld een economische lijn. Na eigen studie en onderzoek, overleg en beraad heeft Prof. Kielstra die vastgesteld. Zal - om slechts twee voorbeelden te noemen - met de rijstcultuur, zooals deze in Nickerie door de klein-landbouwers wordt beoefend en met de citruscultuur worden voortgegaan in de thans gevolgde richting? Of zal de opvolger van den heer Kielstra op zijn beurt nieuwe onderzoekingen beginnen, gevolgd door nieuwe proefnemingen naast de tegenwoordige, wellicht te harer vervanging? Zal de voor de cultures en haar uitbreiding zoo onontbeerlijke irrigatiedienst, die als eerste vrucht van het voortreffelijk onderzoek van Prof. de Vos onlangs is ingesteld, worden gehandhaafd? Het rapport van Prof. de Vos wijst uit, dat ongeveer 138.000 ha grond, geschikt voor den landbouw, in Suriname zonder groote kosten geïrrigeerd kan worden. Men begint in Nickerie, waar voor den klein-landbouw reeds grond te kort komt. Zal men verder gaan langs dezen weg?

Er moet lijn blijven in de zorg van de Surinaamsche Overheid voor het economisch leven van het gewest. De waarborg hiertoe is slechts in het vaststellen van een economisch ontwikkelingsplan gelegen 1 ).

Een tweede noodzakelijke voorwaarde tot het treffen van de juiste maatregelen is, dat Suriname beter gekend worde. De luchtcarteering biedt hiertoe een voortreffelijk hulpmiddel en het is te wenschen, dat het, als het kan met medewerking van het particulier initiatief, op zoo ruim mogelijke schaal worde toegepast.

1) „Herhaalde malen is gevraagd om een plan van ontwikkeling voor Suriname. Een gedetailleerd plan komt mij onuitvoerbaar en ongewenscht voor. Maar een breed opgezet plan, aangevende de hoofdlijnen waarlangs de ontwikkeling van het land systematisch zal worden geleid, een plan dat doelbewust gericht is op versterking van de volksdraagkracht en daardoor geleidelijke voorziening in wat Suriname het meest ontbreekt, d.i. volksvermogen, lijkt mij niet onmogelijk. Niet alleen niet onmogelijk, maar ook noodzakelijk. Want ik kan niet inzien, hoe een land, dat in den toestand verkeert waarin Suriname thans verkeert, ooit een self-supporting land zal kunnen worden, indien de ontwikkeling daarvan niet gezocht wordt langs weloverwogen vaste lijnen, lijnen die systematisch gevolgd worden en waarvan de financiëele consequenties volledig aanvaard worden." (Jaarverslag Surinaamsche Bank. 1931. Blz. 15). 
In zijn belangwekkend artikel „Luchtopnamen in Suriname, vooral met het oog op economische mogelijkheden" 1) schrijft Dr. W. C. Klein m.i.: „Maar wel hoop ik er op te wijzen, dat luchtopnamen, naast veel andere noodzakelijke maatregelen, kunnen leiden tot een breederen kijk op de toekomstige mogelijkheden inzake productie van hout, vleesch, vruchten, rijst en mineralen. En als ik dan den export bekijk, wat aan de hand der zeer goede statistieken voor een ieder mogelijk is en de Surinaamsche statistieken vergelijk met die van Curaçao, de andere Antillen en Nederland, kom ik tot de conclusie, dat de export juist van hout, vleesch, vruchten en rijst door het Rijk zelf en met name door de Nederlandsche Antillen goeddeels zou kunnen worden opgenomen."

Zooals men weet doet de Billiton Maatschappij thans opsporingen in Suriname naar bauxiet en verricht de Standard Oil Company onderzoekingen naar de aanwezigheid van olie. Ook bij de opsporing van sommige delfstoffen kan de luchtverkenning goede diensten bewijzen 2).

Toen ik in Albina was heb ik van de gelegenheid gebruik gemaakt om een kort bezoek te brengen aan St. Laurent en St. Jean, op den rechteroever van de grensrivier, de Marowijne, gelegen in Fransch-Guyana. Dit gebied is het kleinste van de drie Guyana's. De oppervlakte bedraagt $90.000 \mathrm{~km}$ : en het getal inwoners 50.000 , benevens ongeveer 25.000 in het binnenland levende Indianen.

De eenige haven is Cayenne, de hoofdstad. Fransch-Guyana heeft geen spoorwegen en slechts weinig kunstwegen. Evenals Suriname is het voor een groot deel bedekt met reusachtige wouden, maar er is geen houtexploitatie van eenige beteekenis. Ongeveer 3.500 ha van het gebied is bebouwd. De voornaamste gewassen zijn maïs, rijst, katoen, tabak, cacao en koffie.

In 1851 en 1852 werd Fransch-Guyana bestemd tot verbanningsoord voor misdadigers, die op vier plaatsen hun verblijven kregen: Cayenne, les Iles du Salut, de rotsen van de Kourou en bij de Marowijne (St. Laurent en St. Jean). Onder voorlichting

1) „,De Indische Gids”, Februari 1939, Blz. 99.

2) In dit verband moge ik ook de lezing aanbevelen van het artikel "Over luchtverkenning en geologie in Suriname", van de hand van den heer R. IJzerman verschenen in het Tijdschrift van het Koninklijk Nederlandsch Aardrijkskundig Genootschap, 2de Serie, deel LVI, 1939. Aflevering 2, Blz. 236 e.v.

West-Indische Gids XXI 
van den Gouverneur en den Administrateur heb ik de inrichtingen aan de Marowijne bezocht en een tocht gemaakt in de omgeving. Alle gedeporteerden waren aan den arbeid, hetzij op het land, hetzij in de groote, goed geoutilleerde werkplaatsen, welke zich in de nabijheid van de gevangenissen bevinden. Ik heb alle gebouwen bezocht, het ziekenhuis en de boekerij, de bakkerij en de keukens. In materieel opzicht voldoet, naar mijn indruk, de verzorging der gedeporteerden aan redelijke eischen. Dat zij nuttig werk verrichten en een handwerk leeren kan niet anders dan instemming vinden. Eindelijk bezocht ik ook de cellen. Celverblijf in de tropen; vele dagen reizens van het vaderland. Dat is het verschrikkelijke. Het misdrijf moet wel heel zwaar zijn om deze straf te rechtvaardigen. Met alle waardeering voor het vele goede, dat ik zag, viel het mij toch niet moeilijk te begrijpen, dat de Fransche Regeering, enkele jaren geleden, tot geleidelijke opheffing van de strafkolonie heeft besloten.

Gaarne zou ik nog eenige indrukken weergeven van mijn bezoeken, in Suriname gebracht aan de scholen, de ziekeninrichtingen, de leproserieën; van mijn kennismaking met de volkshuisvesting, de opvoedingsgestichten, de jeugdzorg, het vereenigingsleven, even zoovele onderdeelen van het cultureel en sociaal leven, die een afzonderlijke bespreking ten volle zouden veıdienen. Maar te veel vroeg ik reeds van de aandacht en vooral van den - immers veelal ter zake kundigen - lezer van dit tijdschrift. Ik heb een goede herinnering medegenomen aan hetgeen met bescheiden, al te bescheiden, middelen in Suriname werd bereikt door den arbeid van Overheid en particulier initiatief en niet te vergeten de Missie en de Zending, ons allen dagelijks opnieuw ten voorbeeld in toewijding en offervaardigheid, waar het geldt de belangen van het volk, aan hetwelk wij verplicht zijn het zoo gelukkig mogelijk te laten leven onder de bescherming van de Nederlandsche vlag. Mijn bezoek aan ons mooie en in menig opzicht zoo belangwekkende gebiedsdeel in ZuidAmerika heeft mijn overtuiging versterkt, dat, indien wij onzen plicht verstaan en God aan onzen arbeid Zijn zegen schenkt, Suriname eens in staat zal zijn een behoorlijk bestaan te verzekeren aan vele duizenden gezinnen van gekleurde Rijksgenooten. 